\title{
IRRIGATION MANAGEMENT IN PRUNED COFFEE TREE CROP ${ }^{1}$
}

\section{ANSELMO A. DE P. CUSTÓDIO ${ }^{2}$, MANOEL A. DE FARIA ${ }^{3}$, FÁTIMA C.REZENDE ${ }^{4}$, AUGUSTO R. DE MORAIS ${ }^{5}$, MAURÍCIO C. R. LEITE JUNIOR ${ }^{6}$}

\begin{abstract}
It was evaluated the effect of irrigation management on the production characteristics of coffee cultivar Acaiá MG-1474, planted in spacing of $3.00 \mathrm{~m}$ x $0.60 \mathrm{~m}$, pruned in 2004, and irrigated by drip since the planting, in 1997. The experimental designed used was of randomized blocks with five treatments and four replications. The treatments consisted of irrigation management strategies, applying or not applying controlled moisture deficit in layer of 0 to $0.4 \mathrm{~m}$, in dry seasons of the year: $\mathbf{A}=$ no irrigation (control), $\mathbf{B}=$ irrigation during all year considering the factor of water availability in the soil (f) equal to $0.75, \mathbf{C}=$ irrigation during all year considering $\mathrm{f}=$ 0.25, D = irrigation during all year, but in January / February / March / July / October / November / December with $\mathrm{f}=0.25$ and April / May / June / August / September with $\mathrm{f}=0.75, \mathbf{E}=$ irrigation only during April / May / June / August / September with f = 0.25. From July / 2005 to June / 2007 the applied water depth was defined based on Class A pan evaporation (ECA) and the period from July/2007 to June/2008 based on readings of matric potential of soil obtained from Watermark® sensors. Each plot consisted of three rows with ten plants per row, considering as useful plot five plants of center line. The results indicated that the E irrigation management was the most suitable for technical reasons.
\end{abstract}

KEYWORDS: drip irrigation, productivity, coffee plantation, Coffea arabica L.

\section{MANEJO DA IRRIGAÇÃO NA LAVOURA CAFEEIRA RECEPADA}

RESUMO: Foi avaliado o efeito do manejo de irrigação nas características produtivas do cafeeiro da cultivar Acaiá MG-1474, plantado no espaçamento 3,00 m x 0,60 m, recepado em 2004 e irrigado por gotejamento desde o plantio, em 1997. O delineamento experimental utilizado foi o de blocos casualizados, com cinco tratamentos e quatro repetições. Os tratamentos utilizados constaram de estratégias de manejo de irrigação, aplicando ou não déficit controlado de umidade, na camada de $0-0,40 \mathrm{~m}$, nas épocas secas do ano, ou seja: $\mathbf{A}=$ Sem irrigação (testemunha) $\mathbf{B}=$ Irrigação o ano todo, considerando-se o fator de disponibilidade de água no solo (f) igual a 0,75 ; $\mathbf{C}=$ Irrigação o ano todo, considerando-se $\mathrm{f}=0,25 ; \mathbf{D}=$ Irrigação o ano todo, porém em jan. / fev. / mar. / jul. / out. / nov. / dez., com f =0,25 e em abr. / maio / jun. / ago. / set. com $\mathrm{f}=0,75 ; \mathbf{E}=$ Irrigação somente nos meses de abr. / maio / jun. / ago. / set. com $\mathrm{f}=0,25$. No período de julho de 2005 a junho de 2007, a lâmina de água aplicada foi definida com base na evaporação do Tanque Classe A (ECA) e no período de julho de 2007 a julho de 2008, em leituras do potencial matricial do solo obtidas em sensores do tipo Watermark ${ }^{\circledR}$. Cada parcela foi composta por três linhas de plantio, com 10 plantas por linha, considerando-se como parcela útil 5 plantas da linha central. Os resultados indicaram que o manejo de irrigação $\mathbf{E}$ foi o mais indicado por razões técnicas.

PALAVRAS-CHAVE: Gotejamento, produtividade, cafeicultura, Coffea arabica L.

\footnotetext{
${ }^{1}$ Projeto financiado pelo PNP\&D/CAFÉ - EMBRAPA (19.2004.322.06) e extraído da dissertação de mestrado do primeiro autor.

${ }^{2}$ Eng $^{\mathrm{o}}$ Agrônomo, D.Sc. Agronomia, Departamento de Produção Vegetal (Fitotecnia), Jaboticabal, UNESP Univ Estadual Paulista, b1uflagro@yahoo.com.br, bolsista do CNPq.

${ }^{3}$ Prof. Titular, Departamento de Engenharia, Universidade Federal de Lavras (DEG/UFLA), bolsista do CNPq, mafaria@ deg.ufla.br.

${ }^{4}$ Eng $^{\mathrm{a}}$ Agrícola, D.Sc. Agronomia, Irrigação e Drenagem, Departamento de Engenharia, Universidade Federal de Lavras, (DEG/UFLA), frezende@ deg.ufla.br, bolsista do CNPq.

${ }^{5}$ Prof. Associado, Departamento de Ciências Exatas, Universidade Federal de Lavras (DEX/UFLA), , armorais@ dex.ufla.br, bolsista do CNPq.

${ }^{6}$ Doutorando em Recursos Hídricos em Sistemas Agrícolas, (DEG/UFLA), mauricio_cezar_leite@ yahoo.com.br, bolsista CAPES.

Recebido pelo Conselho Editorial em: 30-11-2010

Aprovado pelo Conselho Editorial em: 10-8-2012
} 


\section{INTRODUCTION}

Considered the largest coffee producer and exporter (25\% of world production), in the last 10 years, Brazil produced an average of 37 million $60 \mathrm{~kg}$ bags of processed product. Brazil is also the second largest consumer of coffee. Known as one of the main agricultural activities in the southern region of the state of Minas Gerais, Brazil, the coffee planting is important due to the generation of exchange values and jobs provided to the region. Representing around $50 \%$ of national production of coffee, more than half of the coffee produced in Minas Gerais is harvested in the south and west (CONAB, 2010).

Of all the coffee area destined to the national coffee park, approximately 2.1 million hectares, more than $10 \%$ are under the system of irrigated production $(233,000$ ha), mainly concentrated in the north of the state of Espírito Santo, Triângulo Mineiro region and Alto Paranaíba region in the state of Minas Gerais and in the west of the state of Bahia, Brazil. These $10 \%$ account for almost $25 \%$ of the national coffee production (SANTINATO et al., 2008). Irrigation attends new crops, under implementation phase, and areas already formed and in production. Several studies have been performed in order to determine the water demand of coffee in these two situations. COELHO et al. (2009) studied the effects of periods of irrigation and fertilizer applications on Catuaí IAC 144 coffee productivity in Lavras, the state of Minas Gerais (MG), Brazil, and concluded that drip irrigation, between 06/01 and 09/30, with or without fertigation provided the best productivity levels, and no significant changes to the installment of fertilizers.

LIMA et al. (2008) evaluated the productivity and the yield of irrigated Rubi coffee in the first five crops in Lavras-MG. The authors concluded that the irrigation increased the productivity of coffee, and the depth of $60 \%$ of Class A pan evaporation (ECA), presented the highest average productivity ( 45.12 bags $\mathrm{ha}^{-1} \mathrm{yr}^{-1}$ ), higher than the other irrigated and non irrigated treatments. The non irrigated treatment showed an average yield of 24.00 bags ha $^{-1} \mathrm{yr}^{-1}$.

VIEIRA et al. (2011) determined the total cost per unit of different irrigation systems in coffee culture in four field sizes for a period of ten years and found that the dripping was economically more feasible. The accumulated production of the first six seasons of Acaiá MG 1474 coffee, under drip irrigation in the southern region of Minas Gerais was technically and economically analyzed by OLIVEIRA et al. (2010). The authors concluded that the sale price was $\mathrm{R} \$ 212.00$ per bag of processed coffee (price at the analyzed time), the coffee would be economically viable in non irrigated areas, only if the average productivity was at least 50.90 bags ha $^{-1}$. They also found that drip irrigation was economically viable, providing increased productivity of $33.48 \%$, and higher profits.

Authors like SILVA et al. (2002), SILVA et al. (2003a), SILVA et al. (2003b), COELHO \& SILVA (2005), REZENDE et al. (2006), GOMES et al. (2007), MARTINS et al. (2007) and SILVA et al. (2008) reported that the adoption of irrigation has provided considerable increases in productivity of coffee plantations, which has justified the adoption of this technique by producers.

Among the studies cited there are changes in obtained productivities with irrigation and producers in the south of Minas Gerais and have research results on the benefits of irrigation in coffee. Thus, the aim of this study was to evaluate the effect of the application or not of controlled deficit of soil moisture (different irrigation management strategies) on the productivity of the first three crops of coffee, after conducting a drastic pruning.

\section{MATERIAL AND METHODS}

The study was conducted at the experimental area of the Engineering Department of The University of Lavras (Universidade Federal de Lavras - UFLA), occupying an approximate area of 0.16 ha situated at latitude $21^{\circ} 13^{\prime} 46^{\prime}$ 'S, longitude $44^{\circ} 58^{\prime} 32^{\prime}$ ' $\mathrm{W}$ and average elevation of $908 \mathrm{~m}$. The region of Lavras-MG has an average annual temperature of $19.4^{\circ} \mathrm{C}$, average annual rainfall of $1,529.7 \mathrm{~mm}$ and average relative humidity of $76.2 \%$. According to the climatic classification of 
Köeppen's, Lavras-MG climate is Cwa; temperate humid with dry winter and wet summer, and the air temperature of the warmest month is $22.1^{\circ} \mathrm{C}$ (DANTAS et al., 2007).

The experimental area is the Distroferric Red Latosol type characterized as a loamy soil $(78 \%)$. To characterize physical water to obtain the total water availability (TWA), analyses were performed in the Soil Analysis Laboratory, of the Department of Soil Sciences of the UFLA.

The cultivar used in the experimental area was Acaiá MG-1474 and was implemented in March/1997 at a spacing of $3.00 \mathrm{~m}$ between rows and $0.60 \mathrm{~m}$ between plants and population density of 5,555 plants ha $^{-1}$ and was pruned in October/2004 and irrigated since planting in 1997. All treatments received the same amount of fertilizer through fertigation, except the control which received manual fertilization at the same time. During the experiment, the fertilization of soil and leaf and the cultivation was performed according to the need of the crop.

The experimental design was a randomized block with five treatments and four replications. Each plot consisted of three planting rows with 10 plants per row, considering as useful plot five plants of the center line for productivity assessment. The treatments consisted of irrigation management strategies performed from June/2005 to July/2008; testing the application or not application of controlled moisture deficit, in $0-0.4 \mathrm{~m}$ layer, in the dry season of the year, as follows: $\mathbf{A}=$ No irrigation (control) $\mathbf{B}=$ Irrigation during all year when the plant consumed $75 \%$ of the total availability of water (TWA) in the layer of 0 to $0.40 \mathrm{~m}$, i.e. availability factor (f) equal to 0.75. $\mathbf{C}=$ irrigation during all year considering $\mathrm{f}=0.25, \mathbf{D}=$ irrigation during all year, but in January / February / March / July / October / November / December irrigated with $\mathrm{f}=0.25$ and in April / May / June / August / September irrigated with $\mathrm{f}=0.75, \mathbf{E}=$ irrigation only during April / May / June / August / September with $\mathrm{f}=0.25$. It was used the method of irrigation, using a drip irrigation system of manual drive. The water was distributed to plants using auto-compensating drippers spaced at $0.40 \mathrm{~m}$ between themselves, and as working pressure $300 \mathrm{kPa}$ (30 m.c.a.) and flow rate of $4.29 \mathrm{~L} \mathrm{~h}^{-1}$.

From July/2005 to June/2007 the time to irrigate and the applied water depth were defined according to the balance realized considering the precipitation occurred and the estimated daily crop evapotranspiration combined with the data of the characteristic curve of soil water retention in variable irrigation frequency; following the criteria established for each treatment. The estimate of coffee evapotranspiration was obtained from the Class A pan evaporation (ECA) using the pan coefficient $(\mathrm{Kp})$ and the crop coefficient $(\mathrm{Kc})$ data appropriate to the experimental conditions. In irrigations performed from July/2007 to July/2008; the applied water depth was defined based on readings of the obtained soil matric potential in the Watermark ${ }^{\circledR}$ sensors installed in each of the experimental plots at depths of $0.10 \mathrm{~m}$ and $0.30 \mathrm{~m}$, representing the layers 0 to $0.20 \mathrm{~m}$ and 0.20 to $0.40 \mathrm{~m}$, respectively, combined with retention curve of soil water data.

The climate data used were obtained from the principal climate station of Lavras-MG (Estação Climatológica Principal - ECP), located on the campus of UFLA at a distance of $570 \mathrm{~m}$ from the experimental site, which belongs to the $5^{\text {th }}$ District of Meteorology, in partnership with the National Institute of Meteorology (Instituto Nacional de Meteorologia - INMET) and UFLA. The used data were: air relative humidity, air temperature, precipitation and Class A pan evaporation (ECA).

The coffee harvest of the crops of 2005/2006, 2006/2007 and 2007/2008 was manually done by the stripping method. After the stripping, the total volume and total weight of harvested coffee were obtained. Samples of 10 liters of fruit were taken and weighed and placed in plastic bags of net type and dried in benches suspended in open air to achieve moisture content of $11 \%$. After the drying, the samples were benefited (husk removal) and weighed again. The obtained data were used in the calculations of coffee productivity taking into account the corresponding plot area.

Statistical analysis was performed using the Sisvar ${ }^{\circledR}$ program (FERREIRA, 2008) 4.0 version, after verification of normality of residuals, by the Shapiro-Wilk test, and homogeneity of variances 
by Bartlett test. The means were compared by Scott-Knott test at $5 \%$ probability $(\alpha=0.05)$. To complement the individual analyzes, there was a conjoint analysis of data in order to verify a possible interaction of the strategies factors of irrigation management and harvest (year of production).

\section{RESULTS AND DISCUSSION}

In Figure 1 are the estimated values of Potential Crop Evapotranspiration (ETc) and the values of precipitation (P) from July/2005 to June/2008. For this period there was a concentration of rainfall between the months of November and March and the values, in general, exceeded those of ETc. It is also possible to see that, in general, during the months from April to October, the rainfall was less than the ETc and may have occurred climatic water deficit during the period. It also appears that in the period under study, the values of precipitation during the beginning of the rainy season mostly were below historical averages obtained by climate normals. Despite an adequate rainfall during the period in which the experiment was conducted, on average $1405.4 \mathrm{~mm}$, this showed up with poor distribution of rainfall during the months of the year, justifying the use of irrigation to supply water deficiency.

Year 2005

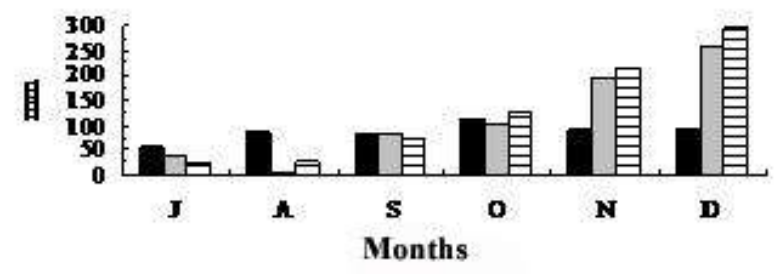

Year 2006

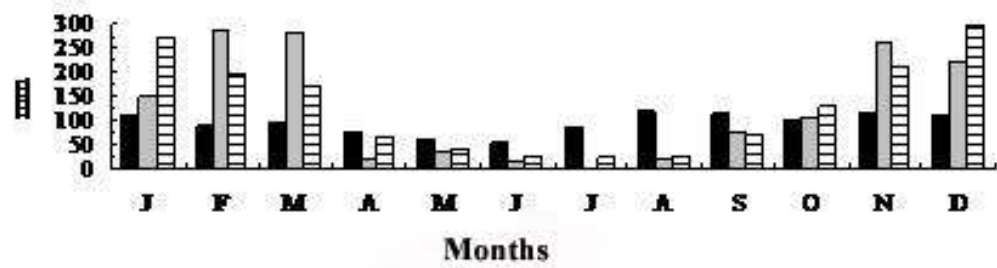

Year 2007

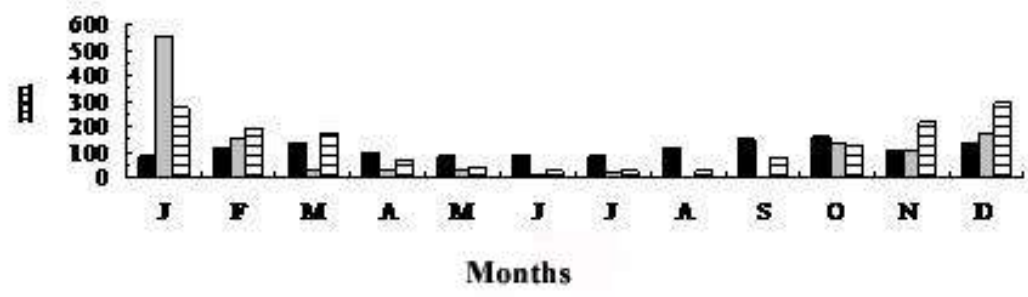

Year 2008

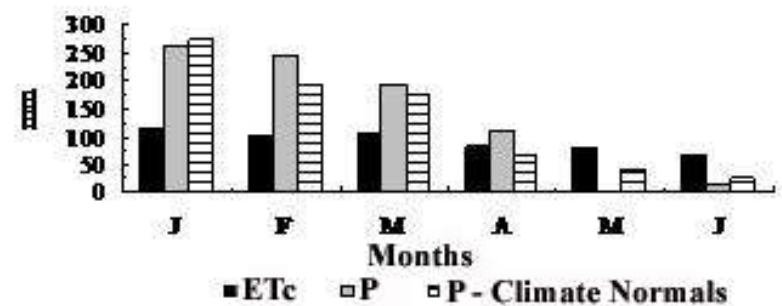

FIGURE 1. Monthly totals $(\mathrm{mm})$ of the estimate of potential crop evapotranspiration (ETc) and precipitation values (P), in the period of July/2005 to June/2008.

In August and September/2007 there was no rainfall $(0 \mathrm{~mm})$, but compared with historical values, together would sum $98 \mathrm{~mm}$. For the month of January of the same year the rainfall was 
$555 \mathrm{~mm}$ higher than the historical average obtained by normal climate, which is $272 \mathrm{~mm}$. Considering only the parameters of ETc and P in the study period, during the months from April to October, monthly water deficit (MWD) were recorded with values ranging from $9 \mathrm{~mm}$ to $100 \mathrm{~mm}$. The depths applied according to different management strategies employed are observed in Figure 2A. Figure 2B shows the sum of depths and precipitation. It appears (Figure 2) that in the period of July/2005 to June/2008, the E irrigation management had the lowest water consumption resulting in savings in water and energy used for irrigation.

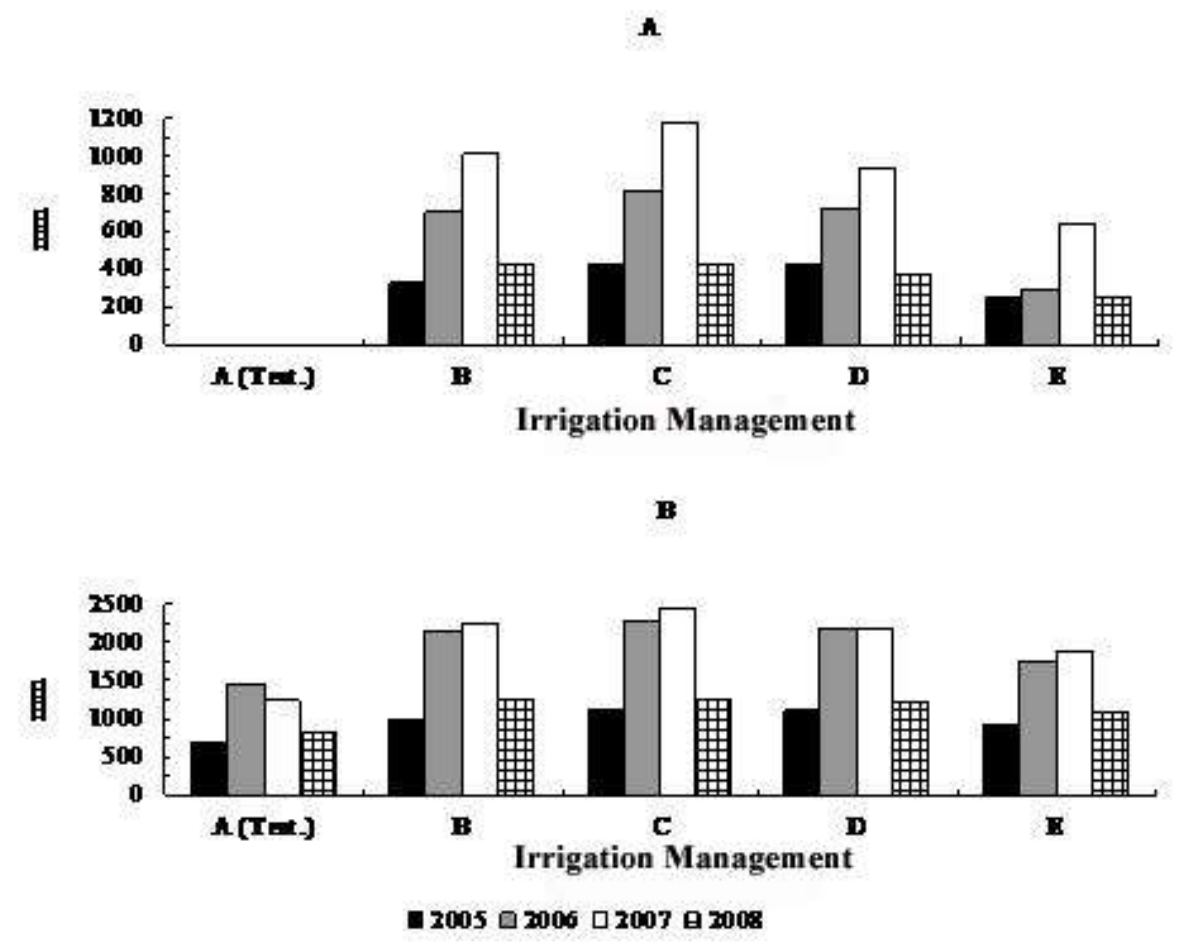

FIGURE 2. Annual depth irrigation (A) and annual depth irrigation increased of precipitations (B), in $\mathrm{mm}$, from July/2005 to June/2008, for different irrigation management.

The climate temperature and relative air humidity averages for the period of July/2005 to July/2008 and from the historical values of normal climate are shown in Figure 3. Relative humidity averages were recorded ranging from 58.3\% during the month of August to a maximum of $78.5 \%$ for the month of January, with annual relative humidity of $71.3 \%$ for the period. The average temperature during the study period varied from $17.1^{\circ} \mathrm{C}$ during the months of June and July to $22.6{ }^{\circ} \mathrm{C}$ in March, with annual temperature average of $20.5^{\circ} \mathrm{C}$. According to SANTINATO et al. (2008), these figures suggest that climatic conditions were favorable to plant and production development of coffee.

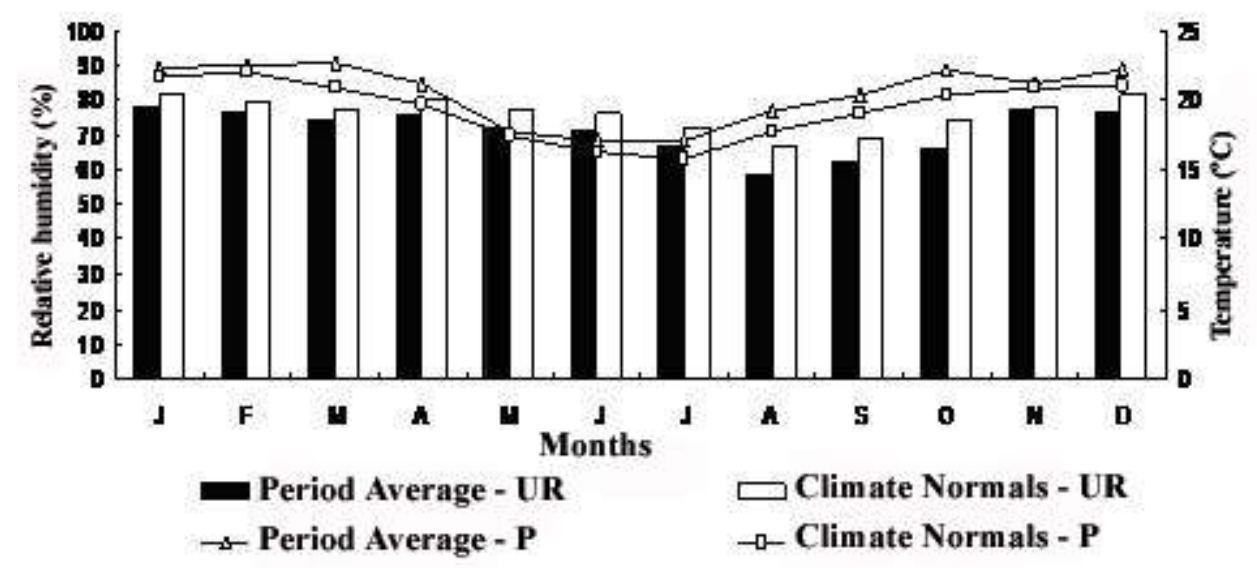

FIGURE 3. Averages of the climate temperature variables and relative air humidity in the period of July/2005 to June/2008 and historical values of the normal climate. 
The summary of the conjoint variance analysis with mean squares for the variable productivity (bags of $60 \mathrm{~kg} \mathrm{ha}^{-1}$ ) obtained in seasons 2005/2006, 2006/2007 and 2007/2008 in different irrigation management strategies is shown in Table 1.

TABLE 1. Summary of the conjoint variance analysis of productivity (bags of $60 \mathrm{~kg} \mathrm{ha}^{-1}$ ) of cv. Acaiá MG-1474 coffee.

\begin{tabular}{lcc}
\hline & G.F. & Variable \\
\cline { 3 - 3 } & & Productivity \\
\hline Crop & 2 & $27223.39^{* *}$ \\
Block (Crop) & 9 & $172.87^{\mathrm{ns}}$ \\
Management & 4 & $45.69^{\mathrm{ns}}$ \\
Crop* Management & 8 & $181.60^{*}$ \\
Error & 36 & 85.88 \\
\hline C.V. $(\%)$ & & 26.44 \\
General Average & & 35.06 \\
ns $^{* *}$ Non significant and ${ }^{* *}$ significant at $1 \%$ of probability by the F test.
\end{tabular}

It is possible to verify that was statistical effect for the variable productivity at $1 \%$ and $6 \%$ of probability by the F test, respectively, for the sources of crop variation and crop interaction and irrigation management. Also in Table 1 it is possible to see that the coefficient of variation was approximately $26.44 \%$.

The unfolding of irrigation management within the crop is presented in Table 2 and it can be seen that the only significant effect at $1 \%$ probability by the $\mathrm{F}$ test is for the irrigation management within the 2006/2007 crop.

TABLE 2. Unfolding of irrigation management within the crop for average productivity (bags $60 \mathrm{~kg} \mathrm{ha}^{-1}$ ) of cv. Acaiá MG-1474 coffee.

\begin{tabular}{lcc}
\hline \multicolumn{1}{c}{ V.F. } & G.L. & Mean Square \\
\hline Management within 2005/2006 & 4 & $70.97^{\text {ns }}$ \\
Management within 2006/2007 & 4 & $332.01^{* *}$ \\
Management within 2007/2008 & 4 & $5.93^{\text {ns }}$ \\
Error & 36 & 85.88 \\
\hline
\end{tabular}

${ }_{\text {ns }}$ Non significant and ${ }^{* *}$ significant at $1 \%$ of probability by the $\mathrm{F}$ test.

Table 3 presents the average values of productivity achieved in each irrigation management strategy in the three crops analyzed. In the harvests of 2005/2006 and 2007/2008 the irrigation management had no effect on productivity, but in the harvest of 2006/2007 there was a significant effect of the irrigation management strategies and the highest values of productivity observed in strategies B and E did not differ between them.

It is possible to verify in Table 3 that the average productivity of crops, regardless of treatment, differed significantly, being classified as an average productivity in 2005/2006 crop, high productivity in 2006/2007 crop and very low in 2007/2008 crop. The increased productivity observed between harvests of 2005/2006 and 2006/2007 in all irrigation management strategies, is due to the plant growth. The significant reduction in productivity in $2007 / 2008$ crop may be due to depletion of the plants caused by high productivity of the previous harvest. 
TABLE 3. Average values of productivity (bags $60 \mathrm{~kg} \mathrm{ha}^{-1}$ ) of cv. Acaiá MG-1474 coffee in the analyzed crops.

\begin{tabular}{cccc}
\hline \multirow{2}{*}{ Management } & \multicolumn{3}{c}{ Crops } \\
\cline { 2 - 4 } & $2005 / 2006$ & $2006 / 2007$ & $2007 / 2008$ \\
\hline A (Test.) & $32.49 \mathrm{a}$ & $65.05 \mathrm{~b}$ & $1.92 \mathrm{a}$ \\
$\mathrm{B}$ & $23.23 \mathrm{a}$ & $82.73 \mathrm{a}$ & $4.93 \mathrm{a}$ \\
$\mathrm{C}$ & $28.54 \mathrm{a}$ & $70.69 \mathrm{~b}$ & $3.23 \mathrm{a}$ \\
$\mathrm{D}$ & $24.69 \mathrm{a}$ & $72.13 \mathrm{~b}$ & $4.17 \mathrm{a}$ \\
$\mathrm{E}$ & $22.35 \mathrm{a}$ & $87.16 \mathrm{a}$ & $2.52 \mathrm{a}$ \\
\hline Average & $26.26 \mathrm{~B}$ & $75.55 \mathrm{~A}$ & $3.35 \mathrm{C}$ \\
\hline
\end{tabular}

Averages followed by the same small letter, in columns, and capital letter, in lines, do not differ statistically by the Scott-Knott test $(5 \%)$.

LIMA et al. (2008) studied for five crops the productivity and yield of coffee with center pivot irrigation in Lavras-MG. The authors found that in the fourth crop (2003/2004) the productivity of non-irrigated treatment reached values of the irrigated treatments, probably due to reduced productivity due to the biennial irrigated treatments and also a possible physiological exhaustion of irrigated plants that obtained high productivities from the first crop. They also observed that compared to other years, the lower intensity of water deficit, may have contributed to high productivity of non-irrigated plants, equating this to the irrigated treatment. The studies conducted by these authors and others like SILVA et al. (2002), SILVA et al. (2003b), COELHO \& SILVA (2005) and GOMES et al. (2007) have demonstrated that irrigation did not prevent the effect of biennial culture, but helped to reduce it since the results indicated that the fall in productivity in irrigated treatments was not as sharp as in non-irrigated treatment. However, SILVA et al. (2008) and FARIA \& SIQUEIRA (2005) found that irrigation failed to attenuate the effects of biennial culture. Establish comparisons of productivity and biennial crop, between experiments, are complex since factors such as cultivar, crop management and weather conditions may be differentiated and influence the performance of the crop.

The productivity values observed in these three crops and the sum (cumulative productivity) at each irrigation management strategy are shown in Figure 4. It appears that there was no significant effect on productivity due to accumulated management strategies adopted. The $\mathbf{E}$ irrigation management strategy, with smaller water depth applied (Figure 2A), may result in greater accumulated productivity (112.03 bags of $\left.60 \mathrm{~kg} \mathrm{ha}^{-1}\right)$ compared to non-irrigated treatment $(99.46$ bags of $60 \mathrm{~kg} \mathrm{ha}^{-1}$ ), and the difference between them of 12.57 bags.

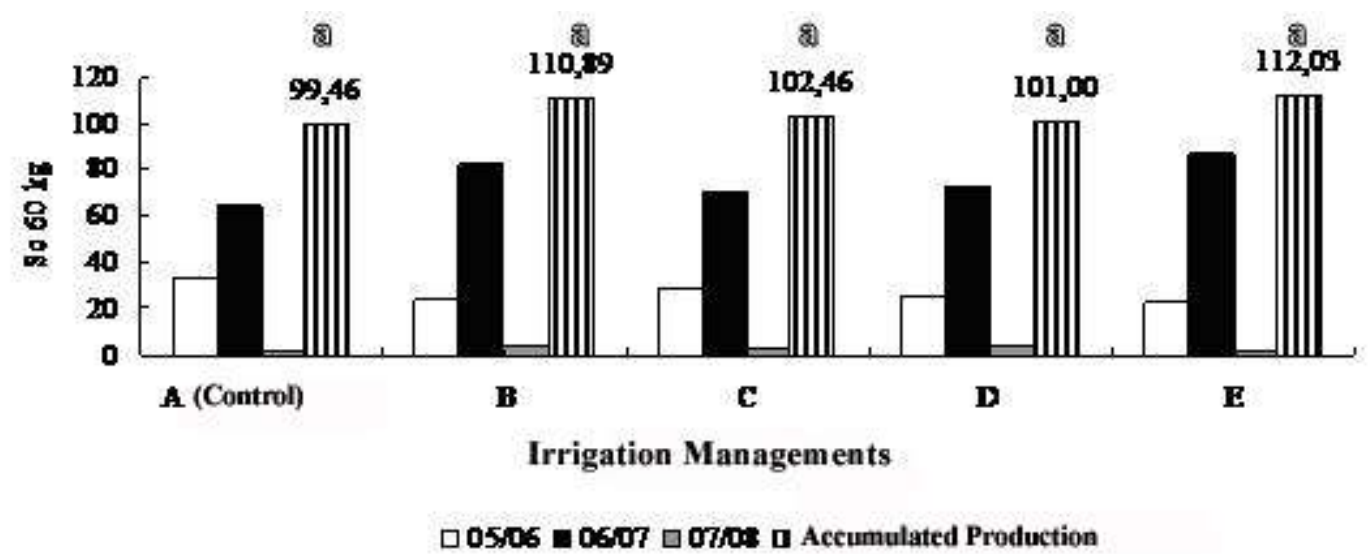

FIGURE 4. Productivity of the treatments to the crops of 2005/2006, 2006/2007 and 2007/2008 and accumulated productivity (bags of $60 \mathrm{~kg} \mathrm{ha}^{-1}$ ), of cv. Acaiá MG-1474 coffee.

It is interesting to note that, to assess the effects of different treatments on coffee culture, it is important to not consider only a crop, since the biennial cycle of productivity may induce 
conclusions not representative of the benefits of the treatments. According to SILVA et al. (2008), LIMA et al. (2008) and CUSTÓDIO et al. (2007) it is important to evaluate the effect of irrigation on the coffee production over several years to obtain more representative responses.

In the $\mathbf{E}$ treatment the management of irrigation was performed only in the months from April to September of the years when all water stored by the layer of 0-40 cm reached consume of only $25 \%$ of available water. According to the phenological phases proposed by CAMARGO \& CAMARGO (2001) the $\mathbf{E}$ irrigation management coincides with the $2^{\text {nd }}$ phenological phase of induction, growth and dormancy of flower buds, and the early 3rd stage (flowering). With the end of irrigation stipulated by the strategy adopted in $\mathbf{E}$ irrigation management, soon after the rainy season started in the region (Figure 1) avoiding problems caused by water deficit in grain formation and expansion, providing better performance in productivity.

In a study of the technical and economic feasibility of using drip irrigation system in the coffee crop in the southern region of the state of Minas Gerais, SILVA et al. (2003a) and OLIVEIRA et al. (2010) concluded that the coffee crop is a profitable activity due to increased productivity being recommended by those farmers.

\section{CONCLUSIONS}

Based on the results of this experiment we concluded that in the 2006/2007 crop (second crop after the pruning) the greatest productivity values were observed in irrigation management strategies $\mathrm{B}$ and $\mathrm{E}$ which did not differ.

In the accumulated productivity of the first three crops after the pruning, the irrigation did not affect significantly the coffee productivity, with just a tendency for increased productivity in the $\mathrm{E}$ treatment that represents the conduction of the farming without deficit of humidity on the soil in the dry season.

Between the irrigation strategies B and E, the best choice is the E strategy due to the smaller annual water depth used for irrigation.

\section{ACKNOWLEDGMENTS}

The authors thank the Brazilian Coffee Research and Development Consortium (Consórcio Brasileiro de Pesquisa e Desenvolvimento do Café - CBP\&D; Coffee Subproject EMBRAPA 19.2004.322.06), by promoting the implementation of this experiment, the Coordination for the Improvement of Higher Education Personnel (Coordenação de Aperfeiçoamento de Pessoal de Nível Superior - CAPES) and the National Counsel of Scientific and Technological Development (Conselho Nacional de Desenvolvimento Científico e Tecnológico - CNPq) for granting the scholarship studies to the first and fifth author.

\section{REFERENCES}

CAMARGO, A. P.; CAMARGO, M. B. P. Definição e esquematização das fases fenológicas do cafeeiro arábica nas condições tropicais do Brasil. Bragantia, Campinas, v.60, n.1, p.65-68, 2001.

COELHO, G.; SILVA, A. M. da. O efeito da época de irrigação e de parcelamentos de adubação sobre a produtividade do cafeeiro em três safras consecutivas. Ciência e Agrotecnologia, Lavras, v.29, n.2, p.400-408, mar./abr. 2005.

COELHO, G.; SILVA, A. M. da; REZENDE, F. C.; SILVA, R. A. da; CUSTÓDIO, A. A. de. Efeito de épocas de irrigação e de parcelamento de adubação sobre a produtividade do cafeeiro 'Catuaí.' Ciência e Agrotecnologia, Lavras, v.33, n.1, p.67-73, jan./fev. 2009.

CONAB - COMPANHIA NACIONAL DE ABASTECIMENTO. Central de informações agropecuárias. Brasília: Ministério da Agricultura e do Abastecimento. 2010. Disponível em: <www.conab.gov.br/conabweb/download/safra/2cafe_10.pdf >. Acesso em: 01 set. 2010. 
CUSTÓDIO, A. A. de P.; GOMES, N. M.; LIMA, L. A. Efeito da irrigação sobre a classificação do café. Engenharia Agrícola, Jaboticabal, v.27, n.3, p.691-701, set./dez. 2007.

DANTAS, A. A. A.; CARVALHO, L. G.; FERREIRA, E. Classificação e tendências climáticas em Lavras, MG. Ciência e Agrotecnologia, Lavras, v.31, n.6, p.1862-1866, nov./dez. 2007.

FARIA, R. T. de; SIQUEIRA, R. Produtividade do cafeeiro e cultivos intercalares sob diferentes regimes hídricos. Bragantia, Campinas, v.64, n.4, p.583-590, 2005.

FERREIRA, D. S. SISVAR: um programa para análises e ensino de estatística. Revista Científica Symposium, Lavras, v.6, n.2, p.36-41, jul/dez. 2008.

GOMES, N. M.; LIMA, L. A.; CUSTÓDIO, A. A. de P. Crescimento vegetativo e produtividade do cafeeiro irrigado no sul do Estado de Minas Gerais. Revista Brasileira de Engenharia Agrícola e Ambiental. Campina Grande, v.11, n.6, p.564-570, 2007.

LIMA, L. A.; CUSTÓDIO, A. A. de P.; GOMES, N. M. Produtividade e rendimento do cafeeiro nas cinco primeiras safras irrigado por pivô central em Lavras, MG. Ciência e Agrotecnologia. Lavras, v.32, n.6, p.1832-1842, nov./dez. 2008.

MARTINS, C. C.; SOARES, A. A.; BUSATO, C.; REIS, E. F. Manejo da irrigação por gotejamento do cafeeiro (Coffea arabica L.). Bioscience Journal, Uberlândia, v.23, n.2, p.61-69, abr./jun.2007.

OLIVEIRA, E. L. de; FARIA, M. A. de; REIS, R. P.; SILVA, M. de L. O. Manejo e viabilidade econômica da irrigação por gotejamento na cultura do cafeeiro Acaiá considerando seis safras. Engenharia Agrícola, Jaboticabal, v.30, n.5, p.887-896, set./out. 2010.

REZENDE, F. C.; OLIVEIRA, S. dos R.; FARIA, M. A. de; ARANTES, K. R. Características produtivas do cafeeiro (Coffea arabica L. cv., Topázio MG -1190), recepado e irrigado por gotejamento. Coffee Science, Lavras, v.1, n.2, p.103-110, jul./dez.2006.

SANTINATO, R.; FERNANDES, A.L.T.; FERNANDES, D.R. Irrigação na cultura do café. 2.ed. Ampliada. Uberaba: O Lutador, 2008. 483 p.

SILVA, A. L. da; FARIA, M. A. de; REIS, R. P. Viabilidade técnico-econômica do uso do sistema de irrigação por gotejamento na cultura do cafeeiro. Revista Brasileira de Engenharia Agrícola e Ambiental. Campina Grande, v.7, n.1, p.37-44, 2003a.

SILVA, A. M. da ; COELHO, G.; FARIA, M. A. de; SILVA, P. A. M.; GUIMARÃES, P. T. G.; COELHO, M. R.; COELHO, G. S. Avaliação do efeito da época de irrigação e da fertirrigação sobre a produtividade e qualidade física do café (safra 1999/2000). Engenharia Agrícola, Jaboticabal, v.22, n.3, p.312-321, set. 2002.

SILVA, A. M. da; LIMA, E. P.; COELHO, G.; COELHO, M. R.; COELHO, G. S. Produtividade, rendimento de grãos e comportamento hídrico foliar em função da época, parcelamento e do método de adubação do cafeeiro Catuaí. Engenharia Agrícola, Jaboticabal, v.23, n.3, p.434-440, 2003 b.

SILVA, C. A. da; TEODORO, R. E. F.; MELO, B. de. Produtividade e rendimento do cafeeiro submetido a lâminas de irrigação. Pesquisa Agropecuária Brasileira, Brasília, v.43, n.3, p.387-394, mar. 2008.

VIEIRA, G. H. S.; MANTOVANI, E. C.; SOARES, A. A.; MONTES, D. R. P.; CUNHA, F. F. da Custo da irrigação do cafeeiro em diferentes tipos de equipamentos e tamanhos de área. Engenharia na Agricultura, Viçosa, v.19, n.1, p.53-61, jan./fev. 2011. 